\title{
Loyalty, Quality and Satisfaction in FMCG Retail Market does Loyalty in Retailing Exist?
}

Mosad Zineldin ${ }^{1^{*}}$, Katty samir Nessim ${ }^{2}$, Emmie Thurn ${ }^{3}$ and David Gustafsson ${ }^{3}$

${ }^{1}$ Professor of Strategic Relationship Management, Linnaeus University, Sweden

${ }^{2}$ Damanhour University, Faculty of Commerce, Damanhour, Egypt

${ }^{3}$ Linnaeus University- Sweden, School of Business and Economics, Växjö, Sweden

\begin{abstract}
This study aims to identify and analyse how customers are experiencing quality, loyalty and satisfaction in the Fast Moving Consumer Goods (FMCG) retail market. The $5 \mathrm{Qs}$ model which includes economical and behavioural attributes is used. A research based on 200 respondents is used to identify differences between various $5 Q$ s attributions. It shows that satisfaction does not automatically lead to loyalty. The price is a ruling attribute that makes the customer chase discounts, no matter who provides it.

Results show that both psychological and economical attributions influence customers' loyalty. The study reveals that organizations have the fantasy that their customers are totally loyal. This is a dichotomous thought because, the customers did not restrict their loyalty to a few organizations, but they are loyal to those organizations which provide them better offers. Independent variable satisfaction correlates substantially with dependent variable loyalty $(.570)$. Holding a membership card which can indicate a commitment attitude was not significant to the loyalty or satisfaction. Thus, the organizations should understand that disloyalty within varying degrees is a reality and a necessary evil.
\end{abstract}

Keywords: Psychology; Loyalty; Satisfaction; Quality 5Qs; Model; Retail market; Fast food

\section{Introduction and Theory}

The concepts of loyalty and satisfaction have been discussed for about five decades in the psychology and consumer-behavior literature. Most studies argue that there is interrelationship between satisfaction and loyalty [1-3]. Previous researches also show that there is a positive relationship between customer satisfaction, Relationship Marketing or Management (RM), Customer Relationship Management (CRM), loyalty and quality.

Quality doesn't improve unless you measure it. It requires an examination of the RM strategies and major quality elements. RM as well as CRM are marketing approaches that revolve around quality, trust, commitment, loyalty and satisfaction $[4,5]$.

Loyalty can be defined as psychological behaviours, including relationship continuance, increased scale or scope of relationship, and recommendation (word of mouth advertising) resulting from customers' beliefs that the quantity of value received from one supplier is greater than that available from other suppliers [6]. Zineldin [3] argues that the customer loyalty and maintenance of customer relationship are in a high degree dependent on the customers' expectations on the product/service quality. Expectations, loyalty and satisfactions are also psychological attributes in explanations of many observed customer behaviors.

RMs strategic value within the FMCG (fast moving consumer goods) retailing sector is questionable [7,8]. Palmatier et al. [9] has found that a lot of managers are disappointed with the outcomes of their RM efforts. Chaston [10] argues that the nature of the FMCG market with high volume sales, large number of customers and low profit margins makes it very expensive to establish long-term relationships. Egan [7] and Vesel and Zabkar [11] further state that customer loyalty programs within the FMCG sector are more costly than common advertising and other traditional marketing activities. The customer loyalty program does not always give any effect in the long run, as the competitors can copy it [7]. When the only loyalty is the size of the discount that the loyalty-program offers, the customer experiences the most satisfaction from the exchange where the discount is the highest $[7,12]$.

Previous researches have often used very simple conceptualizations and models to measure customer loyalty and satisfaction $[13,14]$. Thus, the use of multidimensional construct conceptualizations may be [1].

Zineldin's 5 qualities (5Qs) model provides the company with needed improvement tools from the customers' point of view. By using the five multidimensional quality construct which includes psychological/behavioural and economical dimensions, a company is better able to measure and affect quality, satisfaction and customer loyalty The five quality dimensions are: 1. Quality of object, 2. Quality of infrastructure, 3. Quality of atmosphere, 4. Quality of process and 5. Quality of interaction. Using the 5 Qs to investigate the interrelationship between quality satisfaction and loyalty closes this gap [15].

Egan [7] and Lacey [16] argue that there are little empirical observations, especially in the FMCG (fast moving consumer goods, e.g. food) retail market, done in order to support different RM theories. There is also a lack of information on how relationships are established, maintained, enhanced or, where necessary, terminated [7,11,17]. Accordingly, this study will try to answer the following questions:How effective is Relationship marketing (RM) in the Fast moving consumer goods (FMCG market), in the sense of creating customer satisfaction and customer loyalty? - What quality attributes are critical

*Corresponding author: Mosad Zineldin, Professor of Strategic Relationship Management, Linnaeus University, Sweden, Tel.: +46 7055023 18; E-mail: Mosad.zineldin@Inu.se

Received February 28, 2014; Accepted July 15, 2014; Published July 15, 2014 Citation: Zineldin M, Nessim KS, Thurn E, Gustafsson D (2014) Loyalty, Quality and Satisfaction in FMCG Retail Market does Loyalty in Retailing Exist? J Bus Fin Aff 3: 122 doi:10.4172/2167-0234.1000122

Copyright: ( $) 2014$ Zineldin M et al. This is an open-access article distributed under the terms of the Creative Commons Attribution License, which permits unrestricted use, distribution, and reproduction in any medium, provided the original author and source are credited. 
when generating a loyalty, satisfaction and long-term relationship within the FMCG market?

Does customers' satisfaction regarding retail markets consequently lead to their loyalty?

\section{RM and loyalty}

According to Christopher et al. [18]: the RM concept is emerging as a new focal point, integrating customer service and quality with a market orientation. "Relationship marketing is to identify and establish, maintain, and enhance relationships with customers and other stakeholders, at a profit, so that the objective of all parties involved are met" and "that this is done by a mutual exchange and fulfilment of promises" Relationship Management focuses on customer attractions via relations, interactions and networks (CARIN). One can argue that $\mathrm{RM}$ is a good way to gain a competitive advantage [19].

There is no need for customers to be loyal to one or a portfolio of suppliers in undifferentiated markets, the customer can take the best deal regardless of who provides it [7]. Palmatier et al. [9] found that RM strategies are most efficient in markets with high business to customer interaction, and not that important in the retail section. Palmatier [4] argues further that RM is inherently dynamic, so different factors affect short- versus long-term performance. Olsen [20] suggests that involvement may be an antecedent or a motivational mediator as well as a moderator, between satisfaction and loyalty.

Egan [7] concludes that the relationship mostly exists in the mind of the retailer and that customers do not experience a relationship with their local supermarket. Buckinx and Van den Poel [21] argue that even small or temporary defections from loyal customers can have a great impact on the retailer's profitability, and can lead to total defection in the long run.

A wide range of RM researchers mean that RM efforts affect one or more relational outcomes; trust, commitment, customer loyalty, relationship satisfaction and relationship quality $[3,8,9,12,19,22]$. The organizational psychology literature distinguishes between three types of commitments namely affective, continuance and normative commitment. The differences between them reflect the psychological state that binds the individual to the organization $[23,24]$. Affective commitment should be more important than continuous commitment.

Lacey [16] found that customer recognition and shared values (when the customer feels that the firm practices similar values that the customer have) increase customer commitment. Lacey [7] did not investigate the result between one specific salesperson and the whole firm though. Finally, loyalty does not need to be a result of commitment or trust. Habits have powerful inertia effects on behaviors [25]. Research in consumer psychology found strong ties between habit to behavioural outcomes such as loyalty $[26,27]$.

\section{Satisfaction and loyalty}

Customer satisfaction is generally viewed as a psychological reaction of the customer and an evaluation of emotions. Barnes et al. [28] explain that the overall positive or negative emotions the customer gets about the net value from the services and products that are delivered, define customer satisfaction. Parasuraman et al. [29] and Chang et al., [30] believe that customer satisfaction is a function of perceived service and product quality, which may create a repeating purchase behaviour. Anderson et al. [31] further describe the benefits with high customer satisfaction and implies that decreased price elasticity, increased customer loyalty, decreased future transactions costs, reduced charges imposed on attracting new customers and an improved reputation of the company are a result of high customer satisfaction. A cumulative customer satisfaction involves the customer's overall experience and evaluation of the service or product over time [3,32,33].

Hallowell [6] defines loyalty as "behaviours, including relationship continuance, increased scale or scope of relationship, and recommendation (word of mouth advertising) resulting from customers' beliefs that the quantity of value received from one supplier is greater than that available from other suppliers" Uncles et al. [34] however, define customer loyalty as: "something that customers may exhibit to brands, services, stores, product categories and activities." [34].

Commitment, loyalty and satisfaction could be explored from psychological and economical perspective [35,36]. Many authors believe that satisfaction is a pre condition for loyalty. Customer satisfaction and customer loyalty have a strong relationship (instead we can say are strongly related) and the company's ability to retain and create repurchasing customers is strongly related to the customer satisfaction intensity [30,37]. Hallowell [6] explains that customer satisfaction influences customer loyalty, which may lead to that companies develop profits. The psychological perspective suggests that affective responses such as satisfaction, trust, and attitudinal commitment will induce customers' desires to stay in the relationship. Customers with cumulative satisfied experiences tend to remain affective loyalty to relationship [38]. Chang et al. [30] suggests that unsatisfied customer switches easily to a rival company and the chance for redemption is reduced. Although customer satisfaction is an essential factor in creating customer loyalty, it does not automatically lead to loyalty arise $[13,30]$.

From the economic and investment model, satisfaction is a primary determinant of commitment. Continuous commitment stems from an anticipation of high termination costs associated with quitting a given relationship [22,23]. It results from investment and economic models and calculation of cost and benefit [23].

Finally, other studies have shown that although the customer is satisfied, the creation of customer loyalty differs among products, industries and situations, which also affect customer loyalty $[6,13,30,36]$. A study conducted by $\mathrm{Yi}$ and $\mathrm{La}[39]$ found that customer satisfaction have no direct influence on repurchase intention for lowloyalty customers.

\section{Trust, commitment, membership cards and loyalty in a FMCG Sector}

Food and grocery constituted $53 \%$ of the total private consumption 2008 [40]. The western format of stores is spreading all over the world with concepts such as convenient stores, supermarkets and specialty stores [40]. Prasad and Aryasri [40,41] state that the food industry has traditionally been characterized by transactional marketing, but due to a multitude of changes in marketing environment, demography, cultural attitudes, customer awareness and technology embraced relationship marketing. Anderson et al. [42] and Prasad and Aryasri [41] notice (instead of mean) that the retailing industry faces a dynamic and competitive market; therefore, the importance of customer relationship increases as a tool to gain competitive advantage. This is done by implementing the RM systems and processes to manage customer data and information [42,43]. Anderson et al. [42] and Prasad and Aryasri [40] and Zineldin, et al. [5] argue that RM tools such as 
developing of trust and commitment strategies provide companies with the possibility to react to shifting customer need and wants. When the company gains more knowledge about the customer, studies have shown that the overall customer satisfaction increases [42].

Loyalty can be built by focusing on trust and commitment. Sun and Lin [44] found that a company must first gain the customers trust in order to make them loyal. Commitment was not the most important factor but just trust. They further found that the stores should focus on providing a high service quality through competence, benevolence and problem solving to gain the customers trust.

For a FMCG sector, it is not the physical product that is the main offer. Instead, the store's main "product" is the shopping experience, which includes both the physical products and the staff's service $[43,45,46]$. The shopping experience can be seen as Zineldin's [47,48] concept of PRODSERV. Just as product and service quality, there are many factors that affect the customer's quality perception of the shopping experience, involving the storehouse's location, the speed of the checkout, cleanliness, the politeness of the personnel access to other support services such as parking and packaging and how wide the range is [46]. Matas (or Matsa) [46] says that it costs the FMCG (fast moving consumer goods) market billions of dollars if they cannot offer the customer the product they desire. By not having a full assortment and products in stock, the stores are also taking a risk of losing the customers. Research has also shown that companies that have goods in stock are also cleaner, have faster checkouts and have more polite staff [46].

Meanwhile the empirical finding showed that customers value courtesy, a form of service quality, as the most important aspect when establishing relationships gave the FMCG stores a rating of 2.93 [41]. Zineldin et al. [5] found that quality is the major factor for Customer Attraction via Relations, Interactions and Networks (CARIN).

One basic psychological factor behind loyalty programs and loyalty cards is that people see the value on the card or program as "free lunch" "free money" or "found money". The psychological effect is similar to that of a credit card, only much, much stronger [49]. People spend more. Someone with a $\$ 10$ coupon in his membership loyalty card is more likely to visit that specific store or retailer instead of another retailer. This customer is more likely to spend more than he/she would otherwise be willing to spend. Other psychological factors or benefits are that cards create a bond between the customer and the store, cards can makes payments easy and cards enhance a business's image [49].

On the other hand, customers with low purchasing power are more willing to spend for status-related goods [50]. The use of coupons may, according to signaling theory, signal the low purchasing power consumers and thus can hurt their status. Thus, such consumers are more likely to use coupons if they are privately home delivered. On the other hand, signals that require resources such as money, time and energy can communicate a person's status [51]. Therefore, labels assigned in loyalty cards or programs can serve as observable indicators of status [52].

\section{A 5Qs Model, satisfaction and loyalty}

In an era when intense competition is being greatly facilitated by technology, the need of providing adequate product/service quality will necessitate that companies have to focus attention on issues of improving, measuring and controlling their product/service quality $[43,53]$. Customer loyalty and customer attraction, relationships, interaction and networks (CARIN) as well as the maintenance of the customer relationships are in fact dependent on customer expectation, experience and satisfaction. Also, B2B Relationships. Alliances, Interaction and Networks (BRAIN) are impacted by same factors, i.e. expectations, experience and satisfaction.

Zineldin [54] invented a new model and framework of five generic quality dimensions (5Qs) including psychological, behavioural and economical factors which impact the satisfaction and loyalty of a customer (5Qs). Zineldin (2006) stated that SERVQUAL quality is a classification system concept. Moreover, the five quality dimensions (5Qs) model is an instrument that insures a reasonable level of reliability, validity and significance.

The 5Qs model is more comprehensive and incorporates essential and multidimensional attributes for customer relationship management (CRM), which are missing in the other models attributes $[3,55,56]$. Piskar and Faganel [56] argue that the 5Qs model is tasted and verified in different sectors and can be used in order to measure customer satisfaction and customer loyalty. The 5 generic qualities are:

Quality of object - the technical quality (what customer receives). It measures the core prodserv itself.

Quality of processes - the functional quality (how the prodserv (product and services) provider provides the core prodserv (the technical). It can be used to pinpoint problems in service delivery and to suggest specific solutions.

Quality of infrastructure. Measures the basic resources which are needed to perform the prodserv services: the quality of the internal competence and skills, experience, know-how, technology, internal relationships, motivation, attitudes, internal resources and activities, and how these activities are managed, co-operated and co-ordinated.

Quality of interaction. It measures the quality of information exchange, financial exchange and social exchange, etc.

Quality of atmosphere - the relationship and interaction processes between the customer-company are influenced by the quality of the atmosphere in a specific environment where they operate. The atmosphere indicators should be considered very critical and important because of the belief that lack of frankly and friendly atmosphere explains poor quality and less loyalty.

Figure 1 illustrates the 5Qs model and its constructs. Each single quality dimension of the CRM strategy is impacting the level of satisfaction which is in turn impacting the loyalty. The total quality (TQ) influences the perception of satisfaction and loyalty.

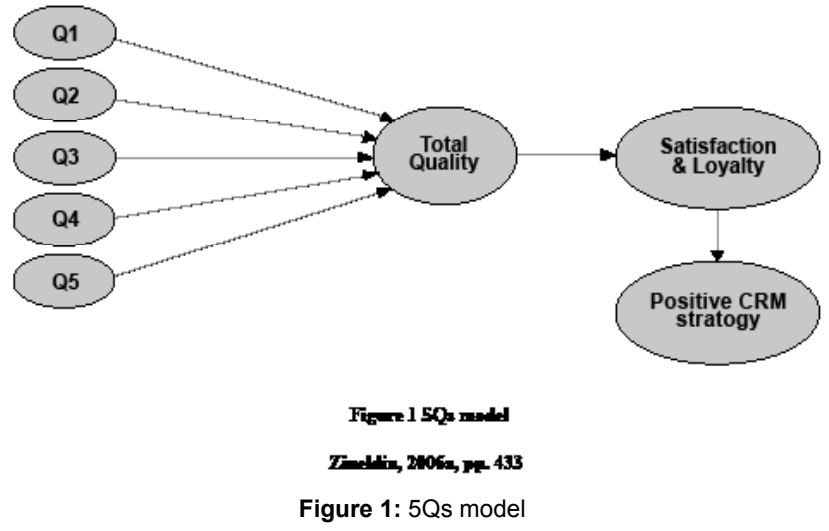


When the 5 Qs model is empirically tested with suitable quality factors, depending on the expectation of the customer and nature of the study, the result will provide a vision of what the customer experienced as the most important qualities. Also, providing the management with an understanding of how quality problems occur and how they can be improved [3,57].

However, the connection between marketing strategy, quality and loyalty might lead to increased competitive advantage, also supported by De Jager et al. [58] TuKuo-Hsien [59]. Piskar and Faganel [56] conclude that satisfied customers do not necessary need to be loyal customers, as they can both repeat orders and buy from competitors. Argue that the $5 \mathrm{Q}$ s model emphasize that quality is used as the key aspect to survive and gain a competitive advantage by establishing long-term relationships.

\section{Material and Methods}

A deductive approach means that studies is based on accepted, general principles, which are applied and used with the aim to explain a specific phenomenon $[60,61,62]$. A questionnaire based on the $5 \mathrm{Qs}$ model's basic items and scales was utilized to survey the customers in the FMCG retail sector. 65, 5\% of the consumers are holding membership cards. $24,5 \%$ more than one store $41 \%$ one store.

To identify and analyze how customers are experiencing quality, loyalty and satisfaction for assessing loyalty, satisfaction and quality, authors utilize items of the 5Qs model. Three questionnaires were performed under a period of one week outside entrance of the FMCG stores City Gross, Willys, ICA Maxi and Coop Extra in Växjö. One questionnaire was also performed in Växjö city to get an objective picture from the customers. When a research study is going to be carried out, it is important to take into account the survey objects, the population and the sample, which can represent and generalize the whole population $[61,63]$. In science, generally two different forms of sample strategies can be applied, probability sampling and nonprobability sampling [62]. A frequently used sampling strategy in nonprobability sampling is convenience sampling or snowball sampling [62].

In this study, two different samplings were used. For the questionnaire, which examined FMCG stores customers and their values; a probability sampling of 250 individuals including both men and women, who were all over 18 years and lived in Växjö, were used? 250 individuals were asked to participate in the survey, but only 200 accepted which gives a responding rate at 80 per cent. Probability sampling was applied since the respondents were selected on a random basis. The four major retails in Växjö are holding 70 percent of the market share. To calculate an appropriate sample size, the authors chose to have $5 \%$ margin of error and $95 \%$ confidence interval. The population was 46.450 units and the authors wanted to have a response rate of $80 \%$. The result showed that the right sample size was at least 250 units; the study therefore selected a sample of 250 individuals. This means that with $95 \%$ accuracy can the authors comment on a topic. For the questionnaire, which examined FMCG companies and their perspective on loyalty and satisfaction, a non-probability sample of 4 FMCG out of 42 stores was used. The big four: Willys, City Gross, Ica Maxi and Coop Extra were the stores with the highest turnover and customers market share.

\section{Data analysis}

SPSS and the website Survey Gizmo were used to analyze the data. Univariate and bivariate analysis were performed to identify the relationship between variables and how their relationship looks like. When dichotomous variables and nominal variables were tested, a contingency table and chi square test was executed. A phi test was also performed to examine the relationship between two dichotomous variables. Independent variable is satisfaction and membership cared while the dependent variable is loyalty.

\section{Results}

\section{Perception/experience of the market}

Table 1 presents an average ranking of respondents' experience of the different the $5 \mathrm{Q}$ dimensions at the different FMCG stores. The highest value a quality factor could get was 5 and the lowest value was 0 . Count and standard deviation are also presented. Table 1 shows that the respondents perceive Q1 (quality of object) as the best quality group, with a total average ranking of 3.37.

The physical products are perceived as the best quality factor with an average ranking of 3.66. The quality factor the respondents perceive as the second most important is price, with an average ranking of 3.54. The three following factors that the respondents consider to be the stores' best qualities is range of products which have an average ranking of 3.36, products are up to date which have an average ranking of 3.25 and products are in stock which has an average ranking of 3.21.

The analyze shows that what customers think are the best qualities of a FMCG store and what they want in a relationship, do not always have to be the same.

\section{Overall satisfaction, membership card (Commitment) and loyalty (SCL)}

The Table 2 shows that 105 of the respondents are both loyal and satisfied. 62 respondents are satisfied but not loyal and 27 is neither. Independent variable satisfaction correlates substantially with dependent variable loyalty $(.570)$. On the other hand the correlation between the other independent variable holding membership card and loyalty is very weak (-.190). Above .3 preferably. That is could be a logical conclusion because most of customers have different membership cards for different stores which means that they are not quite loyal to anyone. The customers use the membership card to get best or discount provided by any store.

Table 3 shows the resulting regression model with the predictors: (Constant), Satisfaction, Membership card and loyalty as the dependent variable. The model explains $34,9 \%$ of the variance in the loyalty. Psychological variable satisfaction makes the strongest contribution to explaining the loyalty. Both Satisfaction and membership are significant at $1 \%(0.008$ and 0.000$)$. The correlation between membership card and loyalty is weak $(\beta-.154)$.

Table 4 is a regression model where the satisfaction is dependent variable an membership card and loyalty are independents variables. The model explains $32,7 \%$ of the variance in the satisfaction. Psychological loyalty makes the strongest contribution to explaining the loyalty (.579). Membership card have no significant at all to the satisfaction.

It means that membership card is not a measure for the loyalty. Loyalty in terms of frequently purchasing regardless membership care holding or not can cause satisfaction.

\section{Discussion}

The Swedish FMCG companies have found that their customers 


\begin{tabular}{|c|c|c|c|c|}
\hline \multirow{3}{*}{$\begin{array}{l}\text { Q1, Quality of object } \\
\text { 1. Physical products }\end{array}$} & $\begin{array}{c}\text { Most } \\
\text { Important }\end{array}$ & $\begin{array}{l}\text { Average } \\
\text { rank }\end{array}$ & Count & StdDev \\
\hline & & & & \\
\hline & 1 & 3,66 & 119 & 1,39 \\
\hline 2. In stock & 5 & 3,21 & 43 & 1,42 \\
\hline 3. Products are up to date & 4 & 3,25 & 32 & 1,27 \\
\hline 4. Range of products & 3 & 3,36 & 108 & 1,35 \\
\hline Summary & & 3,370 & 302 & 5,43 \\
\hline Q2, Quality of process & & & & \\
\hline 5. Price & 2 & 3,54 & 122 & 1,46 \\
\hline 6. Waiting time (behvioural) & & 2,09 & 34 & 0,95 \\
\hline 7. Convenience (behavioural) & & 2,97 & 62 & 1,37 \\
\hline 8. Product arrangement & & 2,44 & 27 & 1,29 \\
\hline Summary & & 2,760 & 245 & 5,07 \\
\hline Q3, Quality of infrastructure & & & & \\
\hline 9. Experience (Behavioural) & & 3,00 & 11 & 0,85 \\
\hline $\begin{array}{l}\text { 10. Competence, right } \\
\text { knowledge and skills } \\
\text { (Behavioural) }\end{array}$ & & 2,74 & 73 & 1,25 \\
\hline 11. Credibility (Behavioural) & & 2,86 & 21 & 1,12 \\
\hline $\begin{array}{l}\text { 12. Inspire me, test new } \\
\text { products (Behavioural) }\end{array}$ & & 2,56 & 16 & 1,22 \\
\hline Summary & & 2,790 & 121 & 4,44 \\
\hline Q4, Quality of interaction & & & & \\
\hline $\begin{array}{l}\text { 13. Responsiveness, } \\
\text { willingness to offer good } \\
\text { service (Behavioural) }\end{array}$ & & 2,85 & 26 & 1,26 \\
\hline $\begin{array}{l}\text { 14. Access, the ability } \\
\text { to contact personnel } \\
\text { (Behavioural) }\end{array}$ & & 2,52 & 21 & 1,26 \\
\hline $\begin{array}{l}\text { 15. Courtesy, treatment of } \\
\text { customers (Behavioural) }\end{array}$ & & 2,93 & 90 & 1,40 \\
\hline 16. Flexibility (Behavioural) & & 2,09 & 22 & 0,90 \\
\hline Summary & & 2,598 & 159 & 4,82 \\
\hline Q5, Quality of atmosphere & & & & \\
\hline $\begin{array}{l}\text { 17. Understanding of the } \\
\text { customers need and wants } \\
\text { (Behavioural) }\end{array}$ & & 2,49 & 39 & 1,36 \\
\hline 18. Lightning, in the store & & 2,00 & 13 & 1,18 \\
\hline 19. Parking & & 2,60 & 69 & 1,45 \\
\hline $\begin{array}{l}\text { 20. Accessibility, space in } \\
\text { store (Behavioural) }\end{array}$ & & 2,64 & 53 & 1,34 \\
\hline Summary & & 2,433 & 174 & 5,33 \\
\hline
\end{tabular}

Table 1: Perception of the $5 \mathrm{Qs}$ at the different stores

\begin{tabular}{|c|c|c|c|c|}
\hline \multicolumn{2}{|c|}{} & Loyalty & $\begin{array}{c}\text { Membership } \\
\text { card }\end{array}$ & Satisfaction \\
\hline \multirow{2}{*}{$\begin{array}{c}\text { Pearson } \\
\text { Correlation }\end{array}$} & Loyalty & 1,000 &,- 190 &, 570 \\
\cline { 2 - 5 } & Membership card &,- 190 & 1,000 &,- 063 \\
\cline { 2 - 5 } & Satisfaction &, 570 &,- 063 & 1,000 \\
\hline \multirow{2}{*}{$\begin{array}{c}\text { Sig. } \\
\text { (1-tailed) }\end{array}$} & Loyalty &. &, 004 &, 000 \\
\cline { 2 - 5 } & Membership card &, 004 &. &, 189 \\
\cline { 2 - 5 } & Satisfaction &, 000 &, 189 & - \\
\hline \multirow{3}{*}{$\mathrm{N}$} & Loyalty & 200 & 200 & 200 \\
\cline { 2 - 5 } & Membership card & 200 & 200 & 200 \\
\cline { 2 - 5 } & Satisfaction & 200 & 200 & 200 \\
\hline
\end{tabular}

Table 2: Correlation between Satisfaction, membership care and Loyalty

\begin{tabular}{|l|rr|l|l|l|}
\hline & $\boldsymbol{\beta}$ & & $\mathbf{P}$ & $\mathbf{R}$ & $\mathbf{R 2}$ \\
\hline (Constant) & & .008 & & \\
1-Membership card & & -.154 & .008 & .591 & .349 \\
2-Satisfaction & .561 & .000 & & \\
\hline
\end{tabular}

Table 3: Regression model: loyalty is the dependent variable

\begin{tabular}{|l|l|l|l|l|} 
& $\boldsymbol{\beta}$ & $\mathbf{P}$ & $\mathbf{R}$ & $\mathbf{R 2}$ \\
\hline (Constant) & & .432 & & \\
1-Membership card & .047 & .430 & .572 & .327 \\
2-Loyalty & .579 & .000 & & \\
\hline
\end{tabular}

Table 4: Regression model : Satisfaction is dependent variable

are price conscious but also appreciate various time saving aspects. Moreover, Morgan and Hunt [22] also found that customers engage in relationship to save money and time but also due to convenience and companionship. The FMCG store thought that their customers perceive convenience as an important aspect when establishing a relationship but it was not shared with the customers. No or very weak correlations were also found between most of the demographic variables such as age, gender, education and satisfaction and loyalty.

The investigation found that $43.5 \%$ of the customers' only reasons to establish a relationship was to save money. Although, $21 \%$ of the respondents mean that the goal for establishing a relationship is to receive better treatment, for example nicer personnel. However, Jain and Gupta [64] mean that a higher degree of service quality can improve this notion and increase the customer satisfaction rate. One conclusion is that it can be more effective to increase the customer switching cost since the customers are not loyal.

By investigating the FMCG stores perception of their customers' satisfaction rate, the study reveals that the stores believe that the customers are more satisfied than they really are with an average ranking of 8.5. It is a similar pattern with loyalty, where the customers rank themselves, as 5.7 while the stores rank their customer as 7.5. Since the FMCG stores perceive their customers as more satisfied and loyal than they really are, they may not be able to get the wanted results from their RM strategy. If the FMCG stores value their customers' satisfaction and loyalty level more than it really is, the theories mean that they do not obtain the full advantage of their RM strategy, hence lowering the effectiveness of the RM strategy.

Sun and Lin [44] explain that if the companies do not know their customers and the customers' perception of the company, then they do not have the acquirements to develop effective RM strategies. The RM strategy will therefore not lead to the desired result and goals. The empirical findings show that customers' perception of companies understanding for their needs and wants, is an average of 2.49 on a scale of 1-5. Since the companies only have a moderate understanding for the customers' needs and wants, the theory indicates that this can be a reason for the customers low loyalty ranking.

The empirical investigation found that respondents are quite satisfied, therefore, Anderson et al. implies that companies can benefit from decreased price elasticity, increased customer loyalty, decreased transaction costs and improved reputation of the company. There is a trend that low prices cause low quality expectations and can therefore generate a high satisfaction rate, even though the TQ rank is low. This research shows only a moderate correlation between satisfaction and loyalty. A customer can get benefits of different loyalty programs 
offered by different competitors without being loyal to all or any of them. Furthermore, both Chang et al. [30] and Bloemer and Kasper [13] have found that customer satisfaction does not automatically lead to customer loyalty.

A very commonly held notion in the RM school is that it is more cost efficient to retain current customers than to attract new ones. Although, this is questionable in this research since the customers have shown tendencies to be quite self-centred as they mostly chase the discount - no matter who provides it.

By offering membership cards or specific membership offers, the FMCG stores want to create loyal customers. Membership card was found as an explaining variable to where the respondents were ranked on the loyalty scale. Although, there was no correlation found between the respondents with just one membership card and loyalty, which the customer loyalty program theory means should exist???? Incomprehensible. This study shows that there is no correlation between membership cards and the satisfaction rate. On the other hand, there is a correlation between membership card and loyalty but only a moderate correlation between loyalty and satisfaction.

When investigating the customers' perception of the FMCG stores five best qualities out of twenty, the empirical investigation showed that the respondents' value typical product quality factors based on the 5Qs model. It illustrates the respondents perception of the FMCG stores qualities, based on the $5 \mathrm{Q}$ model. The empirical investigation presented that the four of the highest ranked qualities are within Q1, which is the quality of object. The $5 \mathrm{Q}$ s model defines Q1 as the technical quality, what the customer receives. Physical products were ranked as the FMCG stores best quality factor. Range of products was seen as the third best quality, which the companies assessed as third best quality. This might imply that product range can be seen as a critical quality factor within the FMCG industry. Desai [65] argues that the assessment of the product quality is influenced by the price of the product. This might explain why the research found that price was rated as the FMCG stores second best quality. The FMCG stores also valued $\mathrm{Q} 1$ as their best quality group.

The empirical investigation shows tendencies that when the customers estimate the various quality factors, they are prone to evaluate more physical and personal perceived aspects such as physical products, products in-stock, products up to date, range of products, price, as well as psychological and behavioural factors such as convenience and courtesy. This might be the reason for the total high average rank in Q1 and Q2. Although, responsiveness ( do you mean to say that although responsiveness exist???), another psychological and behavioural factor gets a relatively high rank which contradicts with these findings.

Q3, Q4 and Q5 include more psychological and behavioural attributes than Q1, and Q2. Q3 records the highest customer scores. Courtesy (Q3) received the highest rank followed by the responsiveness (Q4) and accessibility (Q5). It is not the economical or the physical product that is the main offer instead it is the shopping experience. This is something that the empirical research has shown aligns very well within the FMCG market. This is due to that the customers' both value ?????? incomprehensible the physical aspects when they value the stores best qualities, but also demand service qualities when they evaluate what they want from a long-term relationship with a FMCG store.

In order to create long-term relationship, the empirical investigation shows tendencies that the respondents perceive themselves as quite satisfied but not particularly loyal. This might be due to that loyalty is more affected by the total quality than individual quality factors. The empirical investigation has also showed that there is a moderate correlation between satisfaction and loyalty, which supports the fact that this might be true. But, is there really a connection between satisfaction and loyalty?

\section{Conclusion}

In this study the authors have found that RM, as the current theory presents it, does not provide any effective strategies to create customer satisfaction and loyalty within the FMCG market. The relatively high satisfaction rate is not achieved through RM activities, but instead a result of how low prices decrease the customers' expectations on the stores totals quality.

This argument is based on the findings of a relatively high satisfaction rate even though the total quality was low. The research also found evidence that satisfaction does not automatically lead to loyalty, as there was a moderate correlation between customer satisfaction and loyalty but not a high a loyalty rate. Other authors have earlier also found this result.

$\mathrm{RM}$ does not create loyalty, which also indicates that RM is not effective within the FMCG market. The research has found that price is a ruling factor that makes the customer chase discounts, no matter who provides it.

This study has found that the companies within the FMCG market need to implement more effective RM strategies in order to assure the possibility to reap the benefits from satisfied and loyal customers. Therefore, we raise the question if price is the new customer loyalty program within the FMCG market?

The study shows that while FMCG stores value Q1 as their best quality group, customers evaluate psychological and behavioural variables in Q4, "quality of interaction", as the most important quality group when establishing a long-term relationship

Given all complex psychological factors, customer satisfaction is hardly as straight forward as plugging numbers into the numerator and denominator and calculating the result. In fact, this formula isn't about numbers at all; it's about the relationship between performance and expectations and how these two factors intertwine so as to influence customer satisfaction. In particular, this formula serves as a reminder that no matter how satisfied customers may be, their satisfaction level can be affected by changes in either their expectations or companies' performance. That means companies have to pay attention to both Finally, this study showed that having a membership which can indicate a level of commitment is not significant in relation to the satisfaction. Furthermore, loyalty does not need to be a result of commitment. This result is in conformance with the other research in consumer psychology which found strong ties between habit to behavioral outcomes such as loyalty.

\section{References}

1. Homburg C and Giering A (2001) Relationship Between Customer Satisfaction and Loyalty- An Empirical Analysis. Psychol Market 18: 43-66.

2. Flynn LR, Goldsmith RE (1993) Application of the personal involvement inventory in marketing. Psychol Market 10: 357-366.

3. Zineldin M (2006a) The royalty of loyalty: CRM quality and retention J Consum Market 23: 430-437.

4. Palmatier RW (2008) Relationship Marketing, Marketing Science Institute Cambridge Massachusetts. 
5. Zineldin M (2012) Relationship Management for the Future-studentlitteratur Sweden.

6. Hallowell R (1996) The relationships of customer satisfaction customer loyalty and profitability-An empirical study. Int J Serv Ind Manag 7: 27 - 42.

7. J Egan (2000) Drivers to Relational Strategies in Retailing. Intl J of Retailing D Manage 28: 379-386.

8. Henning Thurau T, Gwinner PK, Gremler DD (2002) Understanding Relationship Marketing Outcomes- An Integration of Relational Benefits and Relationship Quality. J Serv Res 4: 230-247.

9. Palmatier PW, Dant R P, Grewal D, Evans K R. (2006) J Market. 7: 136-153.

10. Chaston I (2000) Relationship Marketing and the Orientation Customers Require of Suppliers- Serv Ind J. 20: 147-166.

11. Vesel P, Zabkar V (2010) Relationship quality evaluation in retailers relationship with customers. Eur J Market. 44: 1334-1365.

12. Chien S, Charles, Mautinho Luiz (2000) The External Contingency and Internal Characteristic of Relationship Marketing. J Market Manage.16:583-595.

13. Bloemer JM, Kasper HD (1995) The complex relationship between consumer satisfaction and brand loyalty. J Econ Psychol. 16: 311-330.

14. Halstead D, Page T R Jr (1992) The effects of satisfaction and complaining behavior on consumer repurchase intentions. J Consum Satisfaction, Dissatisfaction Complaining Behavior. 5: 1-10.

15. Zineldin M, Zineldin J, Vasicheva V (2014) Approaches for Reducing Medica Errors and Increasing Patient Safety. TQM Journal. 26

16. Lacey R (2007) Relationship drivers of customer commitment. J Market Theor Pract. 15: 315-333.

17. Egan J(2004) Relationship Marketing: Exploring Relational Strategies in Marketing- $2^{\text {nd }}$ edition. Prentice Hall Financial Times:London.

18. Christopher M, Panyne A, Ballantyne D (1991) Relationship Marketing: Bringing Quality, Customer Service and Marketing Together. Butterworth-Heinemann, Oxford.

19. Álvarez SL, Casielles VR, Diaz Martin MA (2011) Analysis of the role of complaint management in the context of relationship marketing. J Market Manage. 27: 143-164.

20. Olsen S-O (2007) Repurchase Loyalty: The Role of Involvement and Satisfaction, Psychology and Marketing. 24 : 315-341.

21. Buckinx W, Van den Poel D (2005) Customer base analysis: partial defection of behaviourally loyal clients in a non-contractual FMCG retail setting. Euro $J$ Oper Res.164: 252-268.

22. Morgan RM, Hunt SD (1994) The commitment-trust theory of relationship marketing. J Marketing. 53: 20-38.

23. Allen NJ, Meyer (1990). The measurement and antecedents of affective, continuance, and normative commitment to the organization. J Occup Psychol. 63:1-18.

24. Pritchard MP, Havitz ME, Howard DR (1999). Analyzing the CommitmentLoyalty Link in Service Contexts. J Acad Market Sci. 27: 333-48.

25. Wood S (2010). The comfort food fallacy: Avoiding old favorites in times of change. J Consm Res. 36: 950-963.

26. Labroo AA, Nielsen JH (2010) Half the thrill is in the chase: Twisted inferences from embodied cognitions and brand evaluation. J Consum Res. 37: 143-158.

27. Henderson CM, Joshua TB, Palmatier RW (2011) Review of the Theoretical underpinnings of loyalty programs. J Consum Psychol 21: 256-276.

28. Barnes BR, Fox M, Morris DS (2004) Exploring the linkage between interna marketing, relationship marketing and service quality: A case study of a consulting organization. Total Quality Management and Business Excellence. 15: $593-602$

29. Parasuraman A, ZeithamI VA, Berry LL (1988) SERVQUAL: A multiple-item scale for measuring consumer perceptions of service quality. Journal of Retailing. 84: 12-37.

30. Chang $\mathrm{H}$, Wang HY, Yang WY (2009) The impact of e- service quality, custome satisfaction and loyalty on e-marketing: Moderating effect of perceived value, Total Quality Management and Business Excellence. 20: 423-443.
31. Anderson EW, Fornell C Lehmann DR (1994) Customer satisfaction, market share, and profitability: findings from Sweden. J of Market. 58: 53-66.

32. Zineldin M (2011) Assessing quality in higher education: new criteria for evaluating student's satisfaction Quality in higher education. 17: 231-243.

33. Giese J, Cote J (2000) Defining Consumer Satisfaction, Academy of Marketing Science Review. 2000: 1-24.

34. Uncles DM, Dowling RG, Hammond K (2003) Customer Loyalty and Custome Loyalty Programs. J Consum Market. 20: 294-316.

35. Bendapudi N, Berry LL (1997). Customers' motivations for maintaining relationships with service providers. Journal of Retailing. 73: 15-37.

36. Cortinas M, Elorz M, MLVillanueva (2004) Retail store loyalty management via an analysis of heterogeneity of the service elements. International Review of Retail, Distribution and Consumer Research .14: 407-36.

37. Zeithaml VA (1988) Consumer perceptions of price, quality and value: A means-end model and synthesis of evidence. J Market. 52: 2-22.

38. Oliver RL (1999) whence consumer loyalty? J Market. 63: 33-44.

39. Yi Y,La S (2004) What Influences the Relationship Between Custome Satisfaction and Repurchase Intention? Investigating the Effects of Adjusted Expectations and Customer Loyalty, Psychology and Marketing. 2: 351-373.

40. Prasad JS, Aryasri AR (2008b) Study of customer relationship marketing practice in organized retailing in food and grocery sector in India: an empirical analysis. J Bus Perspective.12: 33-43.

41. Prasad JS, Aryasri AR (2008a) Relationship marketing versus relationship quality \& customer quality \& and customer loyalty in food retailing, Pranjana. $11: 51-71$.

42. Anderson LJ, Jolly DL, Fairhurst EA (2007) Customer relationship management in retailing: A content analysis of retailing trade journals $\mathrm{J}$ Retailing Custom Serv. 14: 394-399.

43. Bellini S, Cardinali MG, Ziliani G (2011) Building customer loyalty in retailing: not all levers are created equal. The International Review of Retail, Distribution and Consumer Research. 21: 461-481.

44. Sun Pi C, Lin CM (2010) Building customer trust and loyalty- an empirical study in a retail context. The Service Industries Journal.30: 1439-1455.

45. Thamaraiselvan N, Raja J (2008) How do consumers evaluate brand extensions - research findings from India.J Serv Res. 8: 43 - 62.

46. Matsa D (2011) Competition and Product Quality in the Supermarket Industry, Quarterny J Eco. 126: 1539-1591.

47. Zineldin M (1995) Bank-company interaction and relationships: some empirical evidence. Int J Bank Market. 13: 30-40.

48. Zineldin M (2005) Quality and customer relationship management (CRM) as competitive strategy in the Swedish banking industry. The TQM Magazine. 17: $329-344$.

49. Hunt M (2008) The Psychology Behind Why Gift \& Loyalty Card Programs Work

50. Rucker Derek D, Galinsky Adam D (2008) Desire to acquire: Powerlessness and compensatory consumption. J Consum Res. 35: 257-267.

51. Ashworth L Darke P and Schaller M (2005) No one wants to look cheap:Tradeoff between social disincentives and the economic and psychological incentives to redeem coupons. J Consum Psychol. 15: 295-306.

52. Drèze X, Nunes JC (2009) Feeling superior: The impact of loyalty program structure on consumers' perceptions of status. J Consum Res. 35: 890-905.

53. Sylvestro R(1990) Patterns of measurement of service performance - empirical results: Managing and Marketing Services in the 1990s. (Edn) Teare R. Moutinho $L$ and Morgan N. Cassell Educational, London.

54. Zineldin M (2006b) The quality of health care and patient satisfaction: An exploratory investigation of the $5 \mathrm{Qs}$ model at some Egyptian and Jordanian medical clinics, International Journal of Health Care Quality Assurance. 19: $60-92$

55. Byrd L (2009) An examination of information technology and it perceived quality issues in single system hospitals in the United States, Doctorial dissertation Auburn University, Alabama USA. 
Citation: Zineldin M, Nessim KS, Thurn E, Gustafsson D (2014) Loyalty, Quality and Satisfaction in FMCG Retail Market does Loyalty in Retailing Exist? J Bus Fin Aff 3: 122 doi:10.4172/2167-0234.1000122

Page 8 of 8

56. Piskar F, Faganel A (2009) A successful CRM implementation project in a service company. Journal Organizacija. 42: 199-208.

57. Zineldin M, Camgös-Akdag H, Vasicheva V (2011) Measuring, evaluating and improving hospital quality parameters/dimensions - an integrated healthcare quality approach. Int J Health Care Qual Assur. 24: 654-662.

58. De Jager JW, Plooy AT, Ayadi M (2010) Do Public Hospitals Respond to the Needs of All Patients in the New South Africa?,Afr J Bus Manag.4 : 133-139.

59. Tu Kuo-Hsien (2009) The effects of the healthcare quality on patient satisfaction: In terms of rehabilitation services. Master Thesis at National Sun yet-sen University-China.
60. DePoy E, Gitlin L (1999) Forskning - en introduktion Lund Studentlitteratur. 61. Olsson H, Sörensen S (2011) Forskningsprocessen Stockholm Liber AB. 62. Jakobsson U (2011) Forskningens termer \& begrepp Lund Studentlitteratur.

63. Rosengren KE, Arvidson P (2002). Sociologiskmetodik Liber AB.

64. Jain S, Gupta G (2004) Measuring service quality: SERVQUAL Vs SERPERF scales VIKALPA 29: 25-37.

65. Desai VV (2011) Patient Satisfaction and Service Quality Dimensions Advances In Management. 4: 40-45. 